\title{
江戸時代末期のグラバーを取扱人とする機械製材について STUDY ON THE MACHINE SAWING TO ASSUME GLOVER HANDLED AT END OF THE EDO ERA
}

\author{
平山䏍男*
}

\section{Ikuo HIRAYAMA}

\begin{abstract}
It is the following points to become clear about the machine sawing by Glover.
The advertisement of the machine sawing by Glover was carried at first by English newspapers, next, translated into Japanese newspaper and reprinted. There were already errors when the article carried by "The Japan Times" was reprinted in Japanese newspaper. It is June 30 from February 26, 1866 issue at least that an advertisement of Glover was carried by English newspapers. The power was steam by coal and a vertical saw, a circular saw and a plane, a gimlet were put in the lumber mill.
\end{abstract}

Keywords : machine sawirg, advertisement, English newspaper, circular saw, vertical saw, steam engine 機械製材，広告，英字新聞，丸鋸，竪鋸，蒸気機関

\section{1. はじめに}

長崎のグラバー邸当主であるT. B. グラバー(Thomas Blake Glover) は天保9(1838) 年、イギリス・スコットランドに生まれた。彼は安政 6(1859)年にイギリス、ジャージン・マセソン商会代理人として来日 し、武器弾薬を始めとする品々の交易や高島炭坑採掘などの事業を 行ったことは多方面で多々取り上げられているものの、グラバーが 江戸時代末、製材業にも関わったことは余り知られてはいない注1)。 本稿では、グラバーが関与した製材業について、それを記した新聞 広告などを通し考察をして、その実態等を明らかとし、更にこの製 材においてどのような機械が用いられたのかなどを関連する資料を 通して明らかにして行きたい。なお、幕末期にはグラバーを始めブ ラキストンなどの外国人が賃挽を試みたが、いずれも失敗に終わっ ている。本稿は、その一端を明らかにすることも目的の 1 つとする。

\section{2.グラバーによる製材取り扱いの実態}

『近代日本建築学発達史』(以下「引用(1)」) には、グラバーが取 扱人として機械製材注2)を取り扱ったことが、『日本新聞』30 号、 西暦 1866 年 4 月 6 日 (慶応 2 年 2 月 21 日） 注3) に掲載されるとして、 以下のような文章が掲載される注4)。

\section{蒸気仕掛の鋸引}

此度鋸引相始候に付左の直段にて木版鋸引の約定仕候

一、小割巾一寸より二寸迄 長开十丈 天保銭二枚

一、板木同三寸より八寸迄年保銭十枚

一、同九寸より一尺二寸迄金一分

同同一尺三寸一尺五寸迄 金一分と天保銭四枚 同同一尺六寸より一尺八寸迄

金一分と天保銭八枚
同同一尺九寸より二尺一寸迄

$$
\text { 同同二尺二寸より二尺四寸迄＜wide>＼cjkstart金二分 }
$$

堅木五割増二致し申候

都而約定注文書は私の名前を加え申候払方は第五番私の用所 に御渡し可被下候

取扱人 グロウル 石川長治郎訳

ところで、この文章は『幕末明治新聞全集』1(以下「引用(2)」)か らの引用注5) とされ、その全文は以下のようになる。なお、本文は 縦書きとなる。

訳者云、左の引札は、原本洋文の外我邦の訳文を添て之を記せ り、仍てそのま〉茲に之を写す。

蒸気仕掛の鋸引

此度鋸引相始候に付左の直段にて木版鋸引の約定仕候 一小割巾一寸より二寸迄 長サ十丈天保銭二枚 一板木同三寸より八寸迄年保銭十枚 一同 九寸より一尺二寸迄金一分 同同一尺三寸 一尺五寸迄 金一分卜天保銭四枚 同同一尺六寸5一尺八寸迄金一分と天保銭八枚 同同一尺九寸5二尺一寸迄 金一分と天保銭十二枚 同同二尺二寸5二尺四寸迄 金二分 堅木五割増に致し申候

都而約定注文書は私の名前を加へ申候払方は第五番私の用所 に御渡し可被下候

取扱人 グロウル

\footnotetext{
* 長岡造形大学造形学部 教授・博士 (工学) ・博士 (造形)

Prof., Faculty of Design, Nagaoka Institute of Design, Dr. Eng., Dr. Design
} 
引用(1)では末尾の訳者を “石川長治郎訳”、引用(2)では “石川 長 治郎訳稿”とし、平仮名の使い回しに幾つかの相違を見ることはで きるものの、ここでそれを問わないとすれば、両者間での異同は僅 少と見て差し支えない。ところで引用(2)には、引用(1)には見られな かった冒頭の 2 行が加えられる。これによると、引用の文章が “引 札”、則ち広告であったことが判明し、更に “原本洋文の外我邦の訳 文を添て之を記せり”、とあることから、本来の記事には加え和文も 添えられていたことが分かるのである。

ところで、更に『日本新聞』30号(以下「引用(3)」) 注6) の原文を 見ておくと以下のようになる。
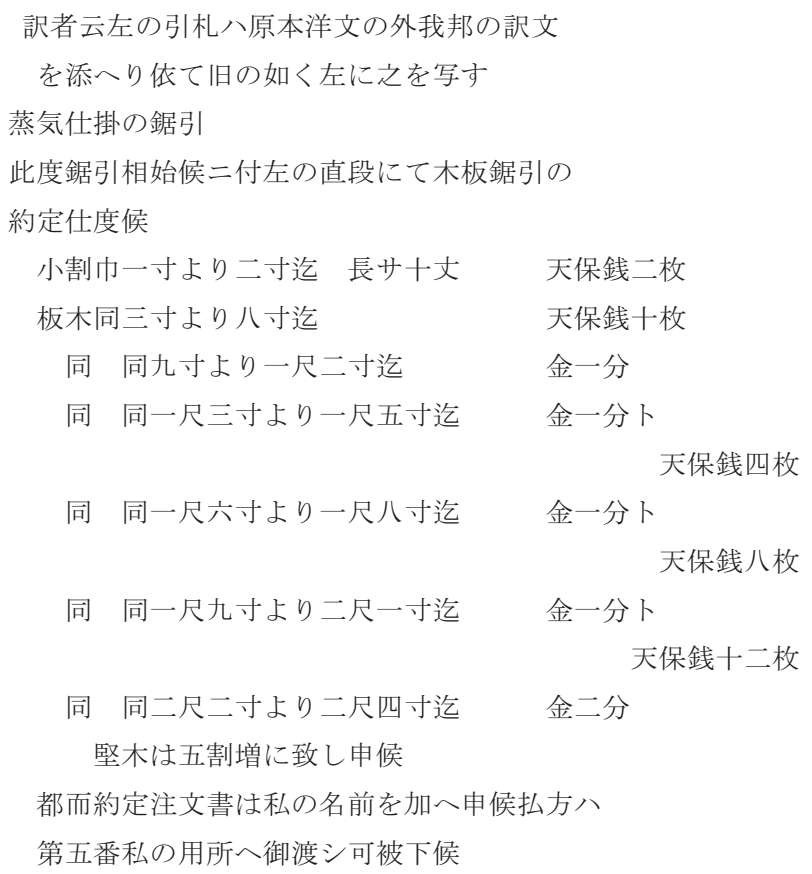

取扱人 グロウル

石川長治郎＼cjkstart訳

引用(3)と引用(2)の相違は、前書き部分に留まり、掲載される值段 は、引用(1)から引用(3)までは同一となる。

しかし、ここ機械製材の挽賃を通覧して比較してみると、やや奇 異な点が目につく。それは、值段の 1 行目と 2 行目では

$$
\begin{aligned}
& \text { 小割巾一寸より二寸迄 長サ十丈 天保銭二枚 } \\
& \text { 板木同三寸より八寸迄年保銭十枚 }
\end{aligned}
$$

とあり、1行目の值段がやや低い点である。

ところで『日本新聞』とは、この時期は英字紙『The Japan Times』 を和訳したものである注7)。その点は、引用(3に翻訳者「石川長治 郎 訳」と付されることから明らかであろう。それでは以上の引用 記事の大本の出典はといえば、これは『The Japan Times』30号（以 下、「引用(4)」) 西暦1866年4月6日に他ならない。この新聞に掲載さ れるグラバーを取扱人とする広告は右段に示した通りである。

引用(4)がこれまでのものと大きく異なるのは挽賃の表示内容であ る。つまり、引用(4)には「巾壱寸占武寸迄 長业十丈 天保銭五枚」 とあり、本来「巾壱寸占武寸迄」の挽賃は「天保銭五枚」で、グラ

\section{YOKOHAMA STEAM} SAW MILLS

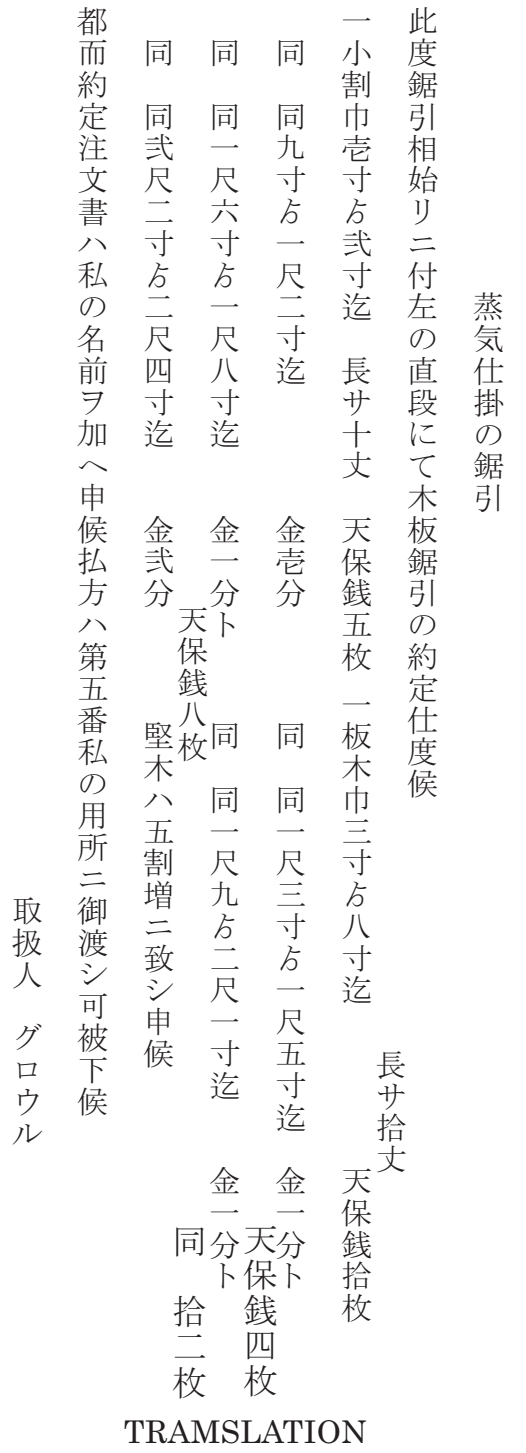

The above Mills being now in WORKING OPERATION, the Managers are pared to enter into contracts for the

SAWING OF TIMBER

at the following rates:-

\begin{tabular}{|c|c|c|c|c|c|c|c|}
\hline & 1. $"$ & to & 2. & in & vid & .. 5 Tempos & \\
\hline Planks & s $3 \|$ & to & 8 & " & " & $\cdots 10$ Tempos & \\
\hline " & $9 "$ & to & 12 & " & "I & ․ 1 Itziboo & \\
\hline " & $13 \mu$ & to & 15 & " & " & $\cdots \quad 1 \frac{1 / 4}{\prime \prime}$ & \\
\hline " & $16 "$ & to & 18 & " & " & $\cdots 1 \frac{1 / 2}{\prime \prime}$ & \\
\hline " & $19 "$ & to & 21 & " & " & $\cdots \quad 1 \frac{3 / 4}{\prime \prime}$ & \\
\hline " & $22 "$ & to & 24 & " & " & $\cdots 2$ & \\
\hline
\end{tabular}

Stripe for mouldings,

For Hardwoods 50\% extra.

All Contracts and Order must

bear the signature of the undersigned and all payments be made to them at their office No.5

GLOVER \& Co. Managers.

Yokohama, Feb. 26th, 1866.

図 1 『The Japan Times』30 号掲載の広告 
江戸時代末期の英字新聞に見るグラバー取扱人の機械製材広告

\begin{tabular}{|c|c|c|c|c|c|c|}
\hline & 西厓年 & 月 & & 揭䡋誌 & 号数 & 借考 \\
\hline & 1866 & & 26 & The Daily Advertiser & 126 & 英文のみ \\
\hline 2 & 1866 & & 27 & The Daily Advertiser & 129 & 英文のみ \\
\hline & 1866 & 3! & 1 & The Daily Advertiser & 130 & 英文のみ \\
\hline & 1866 & 3 & 2 & The Japan Times & 26 & 英文のみ \\
\hline 5 & 1866 & 3 & 3 & The Daily Advertiser & 132 & 英文のみ \\
\hline 6 & 1866 & 3 & 3 & The Daily Advertiser & 133 & 英文のみ \\
\hline & 1866 & 3 & 6 & The Daily Advertiser & 134 & 英文のみ \\
\hline $8 \mid$ & 1866 & 3 & 7 & The Daily Advertiser & 135 & 英文のみ \\
\hline 9 & 1866 & 3 & 8 & The Daily Advertiser & 136 & 英文のみ \\
\hline 0 & 1866 & 3 & 9 & The Daily Advertiser & 137 & 英文のみ \\
\hline & 1866 & 3 & 9 & The Japan Times & 27 & 英文のみ \\
\hline 2 & 1866 & 3 & 10 & The Daily Advertiser & 138 & 英文のみ \\
\hline 3 & 1866 & 3 & 12 & The Daily Advertiser & 139 & 英文のみ \\
\hline 4 & 1866 & 3 & 12 & The Daily Advertiser & 140 & 英文のみ \\
\hline 5 & 1866 & 3 & 14 & The Daily Advertiser & 141 & 英文のみ \\
\hline 6 & 1866 & 3 & 15 & The Daily Advertiser & 142 & 英文のみ \\
\hline & 1866 & 3 & 16 & The Japan Times & 28 & 英文のみ \\
\hline 8 & 1866 & & 21 & The Daily Advertiser & 146 & 英文のみ \\
\hline & 1866 & & 26 & The Daily Advertiser & 150 & \\
\hline 0 & 1866 & 3 & 27 & The Daily Advertiser & 151 & \\
\hline 1 & 1866 & & 28 & The Daily Advertiser & 152 & \\
\hline 2 & 1866 & 4 & 2 & The Daily Advertiser & 154 & \\
\hline 3 & 1866 & 4 & 3 & The Daily Advertiser & 155 & \\
\hline 4 & 1866 & 4 & 4 & The Daily Advertiser & 156 & \\
\hline 5 & 1866 & 4 & 5 & The Daily Advertiser & 157 & \\
\hline 6 & 1866 & 4 & 6 & The Japan Times & 30 & \\
\hline 7 & 1866 & 4 & 7 & The Daily Advertiser & 159 & \\
\hline 8 & 1866 & 4 & 9 & The Daily Advertiser & 160 & \\
\hline 9 & 1866 & 4 & 10 & The Daily Advertiser & 161 & \\
\hline 0 & 1866 & 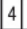 & 13 & The Daily Advertiser & 164 & \\
\hline 1 & 1866 & 4 & 17 & The Daily Advertiser & 165 & \\
\hline 2 & 1866 & 4 & 19 & The Daily Advertiser & 167 & \\
\hline 3 & 1866 & 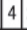 & 21 & The Daily Advertiser & 169 & \\
\hline 4 & 1866 & 4 & 23 & The Daily Advertiser & 170 & \\
\hline 5 & 1866 & 4 & 24 & The Daily Advertiser & 171 & \\
\hline 6 & 1866 & 4 & 25 & The Daily Advertiser & 172 & \\
\hline 7 & 1866 & 4 & 26 & The Daily Advertiser & 173 & \\
\hline 8 & 1866 & 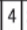 & 27 & The Daily Advertiser & 174 & \\
\hline & 1866 & 7 & 27 & The Japan Times & 33 & \\
\hline & 1866 & 4 & 30 & The Daily Advertis & 175 & \\
\hline
\end{tabular}

\begin{tabular}{|l|l|l|l|l|l|}
\hline 41 & 1866 & 5 & 2 & The Daily Advertiser & 177 \\
\hline
\end{tabular} \begin{tabular}{l|l|l|l|l|l}
42 & 1866 & 5 & 3 & The Daily Advertiser 178
\end{tabular}

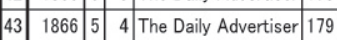
\begin{tabular}{|l|l|l|l|l|}
\hline 44 & 1866 & 5 & 7 & The Daily Advertiser \\
181
\end{tabular}

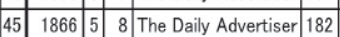
\begin{tabular}{|l|l|l|l|l|l|}
\hline 46 & 1866 & 5 & 9 & The Daily Advertiser 183 \\
\hline
\end{tabular}

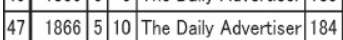
\begin{tabular}{l|l|l|l|l|l|l}
48 & 1866 & 5 & 11 & The Daily Advertiser 185
\end{tabular}

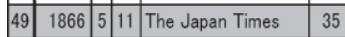
\begin{tabular}{|c|c|c|c|c|}
50 & 1866 & 5 & 12 & The Daily Advertiser \\
186
\end{tabular}

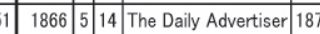

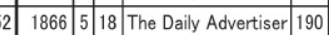
\begin{tabular}{|l|l|l|l|l|l|l}
\hline 53 & 1866 & 5 & 19 & The Japan Times & 36
\end{tabular} \begin{tabular}{|l|l|l|l|l|}
\hline 54 & 1866 & 5 & 19 & The Daily Advertiser \\
191
\end{tabular} \begin{tabular}{l|l|l|l|l}
\hline 55 & 1866 & 5 & 21 & The Daily Advertiser \\
192
\end{tabular}

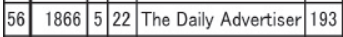
\begin{tabular}{|l|l|l|l|l|l|}
\hline 57 & 1866 & 5 & 23 & The Daily Advertiser & 194
\end{tabular} \begin{tabular}{|l|l|l|l|l|l|}
\hline 58 & 1866 & 5 & 24 & The Daily Advertiser & 195 \\
\hline
\end{tabular} \begin{tabular}{lll|l|l|l|}
\hline 59 & 1866 & 5 & 25 & The Daily Advertiser & 196 \\
\hline
\end{tabular} \begin{tabular}{|l|l|l|l|l|}
\hline 60 & 1866 & 5 & 26 & The Daily Advertiser \\
197
\end{tabular}

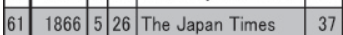
\begin{tabular}{|l|l|l|l|l|l|}
\hline 62 & 1866 & 5 & 29 & The Daily Advertiser & 199 \\
\hline
\end{tabular} \begin{tabular}{|l|l|l|l|l|l|}
\hline 63 & 1866 & 5 & 30 & The Daily Advertiser & 200
\end{tabular} \begin{tabular}{l|l|l|l|l|l|l}
\hline 64 & 1866 & 5 & 31 & The Daily Advertiser & 201
\end{tabular} \begin{tabular}{|l|c|c|c|c|}
\hline 65 & 1866 & 6 & 1 & The Daily Advertiser 202 \\
\hline
\end{tabular} \begin{tabular}{|l|l|l|l|l|l|}
\hline 66 & 1866 & 6 & 2 & The Daily Advertiser & 203
\end{tabular}

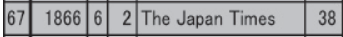
\begin{tabular}{|l|l|l|l|l|l|}
\hline 68 & 1866 & 6 & 4 & The Daily Advertiser & 204 \\
\hline
\end{tabular} \begin{tabular}{l|l|l|l|l|}
\hline 69 & 1866 & 6 & 5 & The Daily Advertiser \\
205
\end{tabular} \begin{tabular}{l|l|l|l|l}
\hline 70 & 1866 & 6 & 9 & The Daily Advertiser 209
\end{tabular} \begin{tabular}{ll|l|l|l}
71 & 1866 & 6 & 14 & The Daily Advertiser \\
212
\end{tabular} \begin{tabular}{|l|l|l|l|l}
\hline 72 & 1866 & 6 & 16 & The Daily Advertiser \\
214
\end{tabular} \begin{tabular}{|l|l|l|l|l|l|}
\hline 73 & 1866 & 6 & 16 & The Japan Times & 40 \\
\hline
\end{tabular} \begin{tabular}{|l|l|l|l|l|l|}
\hline 74 & 1866 & 6 & 19 & The Daily Advertiser & 216 \\
\hline
\end{tabular} \begin{tabular}{l|l|l|l|l|l|l|}
75 & 1866 & 6 & 21 & The Daily Advertiser & 218
\end{tabular} \begin{tabular}{|l|l|l|l|l|l|}
\hline 76 & 1866 & 6 & 23 & The Japan Times & 41 \\
\hline
\end{tabular} \begin{tabular}{l|l|l|l|l|l|l}
77 & 1866 & 6 & 25 & The Daily Advertiser & 221
\end{tabular} \begin{tabular}{|l|l|l|l|l|}
\hline 78 & 1866 & 6 & 26 & The Daily Advertiser \\
222
\end{tabular} \begin{tabular}{|l|l|l|l|l|l|l}
\hline 79 & 1866 & 6 & 30 & The Daily Advertiser & 225 \\
\hline
\end{tabular}

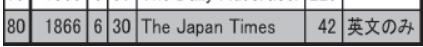

バーを取扱人とする製材では長さにある程度比例した挽貨の体系で あったことが明らかとなる。

\section{3.グラバーによる製材広告の掲載期間}

さて、グラバーを取扱人とする製材の広告は『The Japan Times』 に掲載されることは上に見た通りであるが、前後の日付の新聞を通 読すると、同内容の広告が連続的に掲載されることに気付く。以下、 その掲載期間を具体的に見て行きたい。

さて、グラバーを取扱人とする製材の広告で、引用(4)と同内容の ものは、『The Japan Times』西暦1866年4月6日付30号から同年6月 23 日付41号までと、姉妹紙『The Japan Times’ Daily Advertiser』(以 下、『Daily Advertiser』と記す)の西暦1866年3月26日付150号から 同年6月30日付225号までのほぼ毎号に掲載されている。ここでは既 に述べたように、縦書きの上部に横書きの英文 2 行、縦書きの日本 文9行とともに、横書きとなる英文 23 行が付されている。内容は掲載 されるす心゙てのものが同一であり、この間に挽賃の值上げはなかっ たことが確認されるのである。

さて、広告掲載期間の下限は西暦1866年6月30日付『The Japan Times』42号、『Daily Advertiser』225号より後の号が現存しないた め断定はできないが、一応下限は、現存する『Daily Advertiser』 西暦1866年6月 30 日 225 号としたい。
一方掲載期間の上限は、日本文と英文が併記されるものは『Daily Advertiser』西暦1866年3月26日付150号から見ることができる。と ころが、更に遡って『The Japan Times』『Daily Advertiser』に目 を通すと、和文の部分を持たず、同一内容の英文のみを持つ広告が、 『The Japan Times』の西暦1866年3月2日付26号加 3月16日付28号、 『Daily Advertiser』の西暦1866年2月26日付128号から3月21日付 146号まで見ることができる(表 1 参照)。『Daily Advertiser』『The Japan Times』ともにこれ以前の号が現存するが、これらにはグラバ 一を取扱人とする広告は確認されないことから、西暦1866年 2 月 26 日が広告掲載の上限と見なすことができるのである。ところでこの 日付は引用(4)の最下段に記された日付であり、まさしくこの日が、 グラバーを取扱人とする機械製材の始められた日と言えるだろう。 なお、『The Japan Times』西暦1866年6月30日付42号には再度、和文 を伴わない英文のもののみが記載される。

また、付言すれば、この間の『Dai1y Advertiser』『The Japan Times』 を通覧すると、グラバーによる賃挽広告以外、和文の記事及び広告 は掲載されてはいない。

\section{4.グラバーによる製材広告の対象}

このように見て来ると、グラバーによる木材賃挽の広告は先ず英 文で出され、当初は外国人を対象としたものが、『日本新聞』に転載 され、更に英字紙ではあるが極めて例外的に『Daily Advertiser』 『The Japan Times』にも和文が併記されて掲載がなされたと判断す ることができる。つまり、当初は外国人を対象とした広告が、次い では日本人をも対象としたと考えることができるのである。但し、 上述のように『The Japan Times』西暦1866年6月30日付42号には再 び、英文のみの広告が載ったことから、日本人に対しての広告効果 は見ることができなかったものと推察される。

\section{5.『日本新聞』第 31 号の論説}

ところで、グラバーについての記事が掲載された『日本新聞』30 号の翌号に当たる西暦 18664 月 13 日付『日本新聞』31 号には、『The Japan Times』31 号の論説と思われる和訳が載せられる注8)。この記 事は条約改正について論じつつも、グラバーを取扱人とする機械製 材についての論及を多く見ることができる。先ず、以下ではこの『日 本新聞』31 号の論説全文を掲載し、次いで、グラバーを取扱人とす る機械製材に用いられた機械の実態を示したい。

『日本新聞』31 号の論説はやや長くなるが、以下に引用する通り である注 9)。なお、原文はいずれも縦書きであるが、改行位置は同 じにしている。

[第 1 紙]

$$
\begin{aligned}
& \text { 日本新聞第三十一号 } \\
& \text { 西暦一千八百六十六年四月十三日 } \\
& \text { 我慶応二年三月廿八日注 } 10 \text { ) }
\end{aligned}
$$

前の新聞紙にも条約改正の事を論せり元来方 今に至るまて八大君独交易の利を専にし たりしが自今以後八諸侯と其利を分つに至る 可し従来の条約の仕方二て八不都合頗る多し 


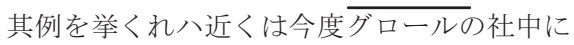
て取立たる蒸気鋸引の一事に就ても旧来の処 [第 2 紙］

置の不便なるを推て知る可し

右鋸引の器械八手軽にして莫大の功用を成す 者なれとも未だ是に相当したる多分の仕事な し其故八近海の諸大名其封内の地二八切り出 し度き材木少からずと雖も国元より横浜に来 るまて材木運送の税を政府の運上所一取立ら れ却て入費倍加する故に態 2 横浜へ持出す者 無し乍去今度条約の第十四則実に行はれて外 国人と日本国中の諸人と自在に交通するに至 らバ是等の税も止て自から器械の用も増加寸 [第 3 紙]

るに至ル可し

今其器械の制度を言はんに先つ一個の平なる 蒸気装置有り是八廿馬力にて二ツの釜あり且 径二尺の鉄輪有りて之に附属す扱鋸引の仕掛 八両個の直なる木格あり此木格の内に二十個 の平鋸ありて運動する仕掛なり又別に二個の 台有り是に於て円形の鋸、鉋の仕掛并に溝を殓 り穴を明くる等の仕掛を成す

平鋸八一寸板を両断するに足る又円形の鋸を 使へは英法一寸巾を十六に割るか如き細微の [第 4 紙]

引割をも成すへし 我曲尺五厘なり 蒸気の力を十分に掛くれバ円鋸八一分時の間 に一千五百の迴転を為し一尺五寸巾の松材、長 さ一丈二尺を引割る可し平鋸にて八右の松材 を大凡十分時の間に三十箇の五分板と成す可 ᄂ

平鋸八大仕事を為す為にて言はべ大木を平等 の厚さの板に切割る抔に用ふ其切様八木品を 台の仕掛にて鋸の刃に当つるなり故に左のミ 人力を費すに及ばず又円鋸ハ之と違ひ大に人

[第 5 紙 $]$

力を用ひざる事を得ず其故ハ此鋸を用る八多 分宮室舟車の小材なるが故に其形状を得せし めんが為に八職人の附添ひ有りて時こ之を置 き直さマ゙れバ其宜を得ざるを以てなり 十二時の間に費寸石炭の量八二噸半乃至三噸 なり然れとも気を附る職人なれ八木屑鋸粉等 をも交セ用る故に大に入費を省く事有り 器械を十分に働か寸る時八平鋸の方一日に厚 サ五分長さ一丈二尺広さ一尺八寸の板を三千 枚製す可し円鋸の方八厚さに拘らず巾一尺八 [第 6 紙］

寸長さ一丈二尺の板一万二千枚を一日に引割 るへし此器械の功力と人工とを比例するに日 本の木挽功者なるも一日の間に右の如き板六
個乃至八個を切割る可きのミ是にて鋸引車と 同し功を成さんに八六百人を用ひされ八能は さるなり又竪硬の材を切るに八殊更利益多し 是八日本の鋸八鈍く成り易く且木の節なと八 別して切れ難きを以てなり

蒸気仕掛の鋸引車を用ふれ八只時間及人力を 省くのミならす剩へ手間代も大に減少寸元来 [第 7 紙]

日本の木挽八巾一尺長さ一丈二尺の板一枚二 付手間代四百文を取る故に長さ十丈二付金二 分に当る然るに蒸気仕掛にて八金一分の費用 にて右と同様の材を切割る事を得可し

此の如く莫大の利有れとも日本人の輙くこれ を用ひん事覚束無し我英国の如き開けたる国 にても始めて蒸気仕掛の紡織車を作り火輪車 を制したる時、職工車工八勿論、其業に差構ひ無 き者まても大に故障を為したり我願く八蒸気 仕掛の鋸にて板を引割るか如く日本の習癖を [第 8 紙］

解く事の速ならん事を

但此鋸引の持主の不都合と云ふ八当時材木の 高直なると不断頼ミ人の多からざるとなり此 地にて八善き松材の長さ一丈二尺厚幅各一尺 の者八金一両二分乃至一両三分なり長岦に於 て八凡三分二朱箱館二て八二分乃至二分二朱 なり此の如く木材の原価高きが故に切割たる 材を支那に運輸して利無き事固ク明なり若し パゼットソンド或は新ゼーランドより此地に材 木を輸入セ八必損耗無かる可し

[第 9 紙］

江戸にて用る木材八多く八尾張の岐曽山或八 内海に住する国ての山より伐出す者にて船の 製造宜しからざる故に運送渡海の手間取甚多 く江戸に到るに及んて其価倍従するなり箱館 に於て八其近地より来るなり扱又仙台にて八 広大の松樹数里間の海湾に蕃殖せり此国主も 之を外国人の交易品となさんと欲する事久し と雖も未其方を得す 今日本国に於て鎖港攘夷を唱ふる者最早是れ 無からん䯉と思はる又思ふに左無くとも若し

[第 10 紙]

諸大名自由交易を許されな八其攘夷家なる者 八自から哀示可し今迄政府にても諸国開港を 好まざる由を唱一実に八ヶ年以前始めて条約 を取結ひし頃八諸侯も真に開港を否ミたり数 百年の習癖一朝一夕に消勫する事八極めて難 くして已に日本の愚民八外国と交通し外国人 と国内に居らしむる事八神へ対して侮慢とな り国法にも戻り且国家の禍と思ひし事疑ひ無 しされ共嶋人交易を好むの気、速に山人の頑愚 
質直に勝ち且日本政府一たび八外国と戦争に

[第 11 紙]

及ばんとせしかども外国の兵勢当る可かざる を知て止ミたり随て諸大名も政府の例に懲り 外国の兵威強盛にして迚も敵し難きを知る上 、方今攘夷の念を断ち交易を為さんと欲する 事左のミ驚くに足らずかくて大坂兵庫の開港 も今近きに在り且外に西海の一港も既に一千 八百六十年に開く可き筈の処延引せしが此以 後諸大名と自由交易始まりなバ其封内の諸港 迄も開け日本国の交易日新月盛なる可しと云

$$
\text { 鈴木唯一訳 }
$$

\section{6. グラバーを取扱人とする機械製材工場の概要}

先ずグラバーが取扱人として機械製材を実施した場所はどこであ ったのだろうか。論説では

近海の諸大名其封内の地二八切り出し度き材木少なからずと雖 も国元より横浜に来るまて材木運送の税を政府の運上所へ取立 られ却て入費倍加する故に態 2 横浜へ持出す者無し [第 2 紙］ としている。『The Japan Times』、『Daily Advertiser』の両紙とも 横浜にて発刊されていたことを考えれば、これは横浜であったとし てよいであろう。なお、グラバー商会は元治元 (1864) 年 5 月から少 なくとも慶応 $3(1867)$ 年まで横浜支店を設けており、この機械製材 を取り扱った慶応 $2(1866)$ 年の社員数が 5 人と最も多い注 11 1)。なお、 グラバー商会横浜支店は居留地 48 街区に位置し注 12 ) 、この地は後 年にモリスン商会とされた注13)。

さて機械製材に用いられた動力は

今其器械の制度を言はんに先つ一個の平なる蒸気装置有り是八 廿馬力にて二ツの釜あり且径二尺の鉄輪有り [第 3 紙］ として、蒸気機関が挙げ、その力は 20 馬力、 2 つの釜があり、径 2 尺の鉄輪が発動機として動くとしている。なお、動力が蒸気機関で あることは『The Japan Times』、『Daily Advertiser』両誌における 広告表題

YOKOHAMA STEAM SAW MILLS

に対応するものともなっている。

そして動力の燃料は、

十二時の間に費す石炭の量八二噸半乃至三噸なり然れとも気を 附る職人なれ八木屑鋸粉等をも交セ用る故に大に入費を省く事 有り [第 5 紙 $]$

として、12 時間で 2 トン半から 3 トンの石炭が使われたものの、木 屑や鋸屑を燃料に用いれば、これらを節約することができるとして いる。

さて肝心の鋸であるが、「平鋸」と「円鋸」の 2 種類の仕組みと働 きが論説に記されている。まず「平鋸」については

鋸引の仕掛八両個の直なる条格あり此木格の内に二十個の平鋸 ありて運動する仕掛なり [第 3 紙］

平鋸ハ一寸板を両断するに足る [第 3 紙 $]$

平鋸にて八右の松材を大凡十分時の間に三十箇の五分板と成す 可し [第 4 紙 $]$

平鋸八大仕事を為す為にて言は、゙大木を平等の厚さの板に切割
る抔に用ふ其切様八木品を台の仕掛にて鋸の刃に当つるなり故 に左のミ人力を費すに及ばず［第 4 紙］

器械を十分に働かする時八平鋸の方一日に厚五五分長さ一丈二 尺広さ一尺八寸の板を三千枚製す可し［第５紙］

とあり、木枠の中に 20 枚の平らな鋸があり、これが動くものとして いる。また、この鋸では一尺五寸巾の松材を 10 分間で 30 枚の五分 厚の板とすることができるとする。つまり、この「平鋸」は大木を均 等の厚さの板に婏くためのものであり、1 日稼働すれば厚 5 分、長 さ 12 尺、巾 1.8 尺の板を 3,000 枚製材することが可能で、逆に言え ば 16 時間余の稼働を工場では考えていたともと言えよう。

このように考えるとこの「平鋸」とはいわゆる「堅鋸」と考える ことができる。

一方、「円鋸」は

又別に二個の台有り是に於て円形の鋸、鉋の仕掛並に溝を鋓り 穴を明くる等の仕掛を成す [第 3 紙 $]$

とあり、いわゆる「丸鋸」であり、工場にはこの他、鉋、錐の器械 もあったことが分かる。そして丸鋸の性能は

円形の鋸を使へは英法一寸巾を十六に割るか如き細微の引割を も成すへし［第 $3 \sim 4$ 紙］

円鋸ハ一分時の間に一千五百の迴転を為し一尺五寸巾の松材、 長さ一丈二尺を引割る可く [第 4 紙 $]$

円鋸八之と違ひ大に人力を用ひざる事を得ず其故八此鋸を用る 八多分宮室舟車の小材なるが故に其形状を得せしめんが為に八 職人の附添ひ有りて時て之を置き直ざ゙れバ其宜を得ざるを以 てなり [第 4〜 5 紙]

円鋸の方八厚さに拘らず巾一尺八寸長さ一丈二尺の板一万二千 枚を一日に引割るへし［第 5～6 紙 ]

とあり、毎分 1,500 回転で、 1 日に巾 1.8 尺、長さ 12 尺の板 12,000 枚を挽割ことも可能とする一方、人間が立ち会えば、 5 厘の精度で 微細な仕事も可能であったことが示されているのである。

以上の記述より、グラバーが取扱人として行った機械製材所は横 浜に位置し、20 馬力と当時としてはやや大型の蒸気機関を動力とし て据え、鋸は「竪鋸」と「丸鋸」、加えて鉋や錐の機械をも備えた本 格的な木工工場であったことが判明するのである。

\section{7. 機械製材の効用}

また、機械製材の有用性について、この論説では 此器械の功力と人工とを比例するに日本の木挽功者なるも一日 の間に右の如き板六個乃至八個を切割る可きのミ是にて鋸引車 と同し功を成さんに八六百人を用ひされ八能はさるなり又堅硬 の材を切るに八殊更利益多し是八日本の鋸八鈍く成り易く且木 の節なと八別して切れ難きを以てなり [第 6 紙]

日本の木挽ハ巾一尺長さ一丈二尺の板一枚二付手間代四百文を 取る故に長さ十丈二付金二分に当る然るに蒸気仕掛にて八金一 分の費用にて右と同様の材を切割る事を得可し [第 7 紙] とあるように、それを強く説いている。前者の引用では、丸鋸 1 台 が木挽人 600 人分に相当し、特に堅木において、日本の鋸は切れ味 が落ちる点を指摘している。また、後者の引用においては機械製材 にかかる費用が人力の 2 分の 1 に過ぎないことを誇示し、機械製材 の人力に対する優位性を強く説いているのである。 


\section{8. さいごに}

以上、グラバーを取扱人とする機械製材について、『The Japan Times』誌などの考察し、更にグラバーを取扱人とする機械製材にお いて用いられた機械類については、『日本新聞』31 号に掲載される 記事の読解を行ったが、明らかになるのは以下の諸点である。

1 ）グラバーを取扱人とする機械製材の広告は当初、英字紙に掲載 され、これが『日本新聞』に翻訳転載後、更に『幕末明治新聞 全集』などに掲載された。

2 ) 『The Japan Times』掲載の原文は、『日本新聞』へ転載の段階で 既に錯誤があり、以後はそれらが改められないままであった。

3 ) 『The Japan Times』『Daily Advertiser』にグラバーを取扱人と する木材の賃挽広告が掲載された期間は西暦 1866 年 2 月 26 日 号から少なくとも同年 6 月 30 日号である。

4 ）グラバーを取扱人とする賃挽広告は当初『The Japan Times』な ど紙上に英文のみが掲載され、次いで和訳文も併せて掲載され、 また英文のみとなった。

5 ) グラバーを取扱人とする賃挽広告には和訳文も併記され、日本 人も対象としていたと考えることができる。

6 ) グラバーを取扱人とする機械製材は、横浜において行われたと 考えられる。

7 ）グラバーを取扱人とする機械製材において、動力は石炭による 蒸気式のものであった。

8 ）この製材所には動力に加え竪鋸、丸鋸及び鉋、錐が置かれた。

9 ) この製材所の竪鋸は 20 枚の歯を備え、1.8 尺巾板の製材が可能 であった。

10）この製材所に設置された丸鋸は毎分 1,500 回転し、巾 1.8 尺ま での材を挽割り、5 厘の精度で加工が可能であった。

11）『日本新聞』31 号における論説では、機械製材の優位性を強く 訴えている。

\section{注}

注 1 ）杉山伸也: 明治維新とイギリス商人ートーマス・グラバーの生涯-、岩波 新書新版赤290、1993.7

(2)アレキサンダー・マッケイ、平岡緑訳：トーマス・グラバー伝、中央公 論社、1997. 1

(3)内藤初穂 : 明治建国の洋商 トーマス・B・グラバー始末、アテネ書房、 2001.2

などの研究書、伝記類にもグラバーが製材を取り扱った旨の記述はない。 注 2 ）引用する記事中では「鋸引」の文字が用いられているが、本文中では一 般的な「製材」「賃婏」の語も用いた。

注 3）以下、年月日は原則西暦を用い、和暦は（ ）内に元号とともに示寸 注 4）日本建築学会編: 近代日本建築学発達史、丸善、1972.9、2001. 12 復刻、 pp. $424 \sim 425$

注 5）尾佐竹猛：幕末明治新聞全集 1、pp. 431 432、大誠堂、1934. 10

注 6）北根豊編：日本初期新聞全集 8、pp. 43、1987. 10

注 7) 北根豊編:日本初期新聞全集別巻, pp. 38 , 平成 12 (2000). 2

注 8）基本的に、この時期の『日本新聞』は『The Japan Times』を翻訳して いたとされる。但し、『The Japan Times』31 号は現存していないため、英 語の本文は明らかではない。北根豊編：日本初期新聞全集別巻、pp. 38、 2000.2 参照。

注 9）北根豊編：日本初期新聞全集 8、pp. 60 61、1987. 10。なお、本史料は、 尾佐竹猛：幕末明治新聞全集 1 、 pp. 432 435、大誠堂、1934.10、にも掲
載されるが、語句に若干の相違が見られ、正確さの点でやや劣る。 注 10）北根豊編：日本初期新聞全集 8、pp. 60、1987.10 によれば、これは慶 応 2 (1866) 年 2 月 28 日の誤りといされる。

注 11）杉山伸也: 明治維新とイギリス商人ートーマス・グラバーの生涯-、岩 波新書新版赤 $290 、$ pp. 74 及び表 3、1993.7。なお、表 3 で慶応元 (1865) 年 と慶応 $3(1867)$ 年の社員数はいずれも 2 人とあり、横浜支店では機械製材取 り扱いの広告掲載を始めた慶応 2 (1866) 年の時点における社員数が最も多 かったことになる。

注 12）内藤初穂：明治建国の洋商 トーマス・B・グラバー始末、pp. 98、前 掲

注 13）佐々木茂市：日本絵入商人録、1886. 6

（2009年11月 9 日原稿受理，2010年 3 月 1 日採用決定） 